\title{
STATUS OF WOMEN IN THE HEIAN PERIOD (794 -1185): A STUDY OF THE LITERARY WORKS OF MURASAKI SHIKIBU AND SEI SHONAGON
}

\author{
Faezah Kassim and Abd. Wahid Jais
}

\section{Introduction}

The period of Heian was the peak in Japanese literary development. The era witnessed the rise of Japanese-based literature and the diminishing of Chinese-based literature. The development of Japanese literature was attributed to contributions of women, particularly from noblewomen and those from the upper class. Two female authors who were often highlighted by historians and writers are Murasaki Shikibu and Sei Shonagon. Their literary works were emphasized and studied since their writings represented women's viewpoints during the Hein period. In most cases, literature is a representation of life, and life is a social reality. ${ }^{1}$ Observers perceive that writers usually disclose or describe the conditions during their lifetime to reflect the culture and society of that particular era. ${ }^{2}$

According to Ismail Hussein, writers use words to express their feelings, thoughts, emotions, attitudes and ambitions in the context of the society they lived in. ${ }^{3}$ In this study, three literature works by the above-mentioned female writers of the Heian period have been chosen as the main reference sources since their literature works have shown great achievement in the development of Japanese prose. To historians, these novels provide a vivid picture of life at court, with clear descriptions of events and real insights into the lives of noble men and rulers during that time. Through these literature works were written by women, the status and role of women as well as their status from the political, economic and social aspects is highlighted by their works. Thus, this study will also analyze the status and role of women during the Heian period based on the perspectives of these two women writers.

\section{The Heian Period (794 -1185)}

Prior to the Heian period during the administration of the Yamato clan, around 710, Nara was the administration as well as the arts and Buddhist development center. In 784, the political capital city was transferred to Nagaoka. Ten years later, in 794, the 50th emperor, Emperor Kammu of Japan developed Heian-Kyo (Kyoto) to make it the capital city. This new capital city was the center of the imperial government

1 Rene Wellek and Austin Warren, Theory of Literature, New York: Harcourt Brace \& World Incorporated, 1956; Marlies K. Danzinger and Wendell Stacey Johnson, The Critical Reader: Analyzing and Judging Literature, New York: F. Ungar Pub. Co., 1978.

2 Rene Wellek and Austin Warren, Theory of Literature, 1956.

3 Observations by Ismail Hussein in Wan Rafaei Abdul Rahman, Psikologi dalam Konteks : Satu Pendekatan, Bangi : Universiti Kebangsaan Malaysia, 1994, p 17. 
for nearly 1100 years, until the Meiji period. The Heian period saw the emergence of the aristocratic class, especially from the Fujiwara clan. The cultural relationship with China went through an important transformation. The emphasis was not on the adoption of cultural characteristic anymore; instead, the focus was on assimilation and harmonization, adopting from the Chinese to complement the local environment and preferences. ${ }^{4}$ In other words, Japanese civilization attempted to achieve its intellectual maturity without depending on the Chinese culture for its literary development. In the year 960, the Japanese decided to end official relationship with China. This prompted a renewed cultural development and image. During this time, the development of localized Japanese script or Kana took place. The Kana system brought about the development of poetry (waka), prose and literary activities in Japanese language. Among the literature works produced during the period was the legendary Genji Monogatari by Murasaki Shikibu. ${ }^{5}$

\section{Background of Writers and Literary Works}

Murasaki Shikibu and Sei Shonagon were two women writers who made major contributions to the development of Japanese literature. Genji Monogatari, Murasaki Shikibu and Makura no Soshi were three literary works from one particular period that emerged in the mid-Heian period around 1000 BC. These three literary works were considered spectacular by most laureates and historians. Murasaki Shikibu was a female writer born in 978 . Some observers think that she might have been born in $973 .{ }^{6}$ Murasaki was her given name while Shikibu referred to her father's position in the imperial court. She was the daughter of Fujiwara Tametoki, who was from an imperial family educated in Chinese classics; he worked as an imperial officer on the Board of Rites. ${ }^{7}$ Though Murasaki's father only wanted his sons to excel in education, Murasaki took the initiative to join her brothers' classes. In fact, Murasaki became more proficient than her brothers. ${ }^{8}$ However, Murasaki was denied any formal education. Instead, with her father's help, she learned Chinese characters and slowly learnt to read Chinese texts.

Murasaki lived with her father for several years while he was the governor in Echizen Province. When she was a teenager ${ }^{9}$, she was married Fujiwara no Nobutaka, a royal army lieutenant. Unfortunately, Nobutaka passed away due to an epidemic in $1001 .{ }^{10}$ Her father sent her to the court to be the lady-in-waiting to Empress Akiko. Murasaki secretly taught the Empress to read in Chinese and Chinese poems. During this period, it was considered an offence for the lady-in-waiting from the lower classes

$4 \quad$ Faezah Kassim, Agama dan Falsafah di Jepun: Perkembangan dan Pengaruh Terhadap Pemikiran Orang Jepun, Kota Kinabalu: Universiti Malaysia Sabah, 2004, p 4.

5 Azhar Mad Aros, TITAS, Shah Alam: Penerbit Fajar Bakti Sdn.Bhd, 2000, p 366.

6 In this period, it was difficult to determine a woman's real name and date of birth, including Murasaki's even though she was a famous writer.

7 William J. Puette, Guide to The Tale of Genji, Tokyo: Charles E.Tuttle Company, 1983, p 50.

8 Arthur Waley (ed), The Tale of Genji: A Novel In Six Parts By Lady Murasaki , England: George Allen and Unwin Ltd., 1973, p 7.

9 Some researchers state that Murasaki got married in her early 20s. During that time, a girl who married after her teens would be considered as having a late marriage.

10 Richard Bowring, Murasaki Shikibu: The Tale of Genji, England: Cambridge University Press, 1988, p 4. 
to teach an Empress. ${ }^{11}$ During that time, Murasaki started to keep a diary about her personal thoughts as well as the court environment, the dressing style and behavior of noble women. She wrote about court events, festivals and scandals. In 1003, Murasaki started to write Genji Monogatari (The Tale of Genji) after she was asked by the Empress to write something entertaining; the Empress deemed works produced at that time were utterly boring. ${ }^{12}$

Murasaki's life was very eccentric. By that time, Murasaki was already known as a poet. In her diary, she admitted that she criticized the behavior of men at court through her poetries. As a result, people around her regarded her as someone who was too concerned with ethics. ${ }^{13}$ Murasaki preferred to be alone following the death of her close family members: her husband, mother and sister. She rarely socialized and was considered quite arrogant. ${ }^{14}$ Eventually the morose Murasaki stopped writing her diary by 1010. After that, not much was known about her life even though her name was still listedas a lady-in-waiting for Empress Akiko in 1025. But by 1031, her name disappeared from the list. ${ }^{15}$

Besides Murasaki Shikibu, there was another female writer from the same period known as Sei Shonagon. Sei Shonagon's actual name is not known but she was called Shonagon, which means Minor Counselor at court. Some scholars identified her actual name as Nagiko. She was the writer of Makura no Shoshi, which was based on her life story while she was the lady-in-waiting for Empress Sadako. Sei Shonagon created a genre of writing known as zuihitsu, which is a writer's collection of observations. She wrote a very detailed account of her life. Every event that had taken place was well described. Morris made the following comment about Shonagon:

...enables us to imagine what life was like for the upper-class Japanese women a thousand years ago. ${ }^{16}$

She was born in 965 . Her father was Motosuke ${ }^{17}$ from the Kiyowara clan. He worked as a provincial officer and was a well-known scholar and poet. Shonagon was married to Tachibana no Norimitsu and had a son. Little was known about her life after her court service ended. Shonagon also did not mention much about her family relationship except her father's name, which was mentioned once in her writings. ${ }^{18}$ In the work of Makura no Soshi, Shonagon explains how the lady-in-waiting would be tested by the Emperor and Empress from time to time on her knowledge and memorization of poetry from

11 Arthur Waley, The Tale of Genji by Lady Murasaki, translated from Japanese, London: Allen \& Unwin, 1935, p ix.

12 Arthur Waley, The Tale of Genji by Lady Murasaki, translated from Japanese, $\mathrm{p} 51$.

13 Murasaki gave numerous comments on how women were supposed to behave. She showed displeasure towards noble women who tried to show off their talents and freely mixed around with men.

14 William J. Puette, Guide to The Tale of Genji, p 53.

15 Richard Bowring, Murasaki Shikibu :The Tale of Genji, p 5.

16 Ivan Morris, The Pillow Book of Sei Shonagon, New York : Columbia University Press, 1991, p xiv.

17 Ivan Morris, The Pillow Book of Sei Shonagon, p 9. Motosuke could not be confirmed as the real or adopted father of Sei Shonagon

18 Ivan Morris, The Pillow Book of Sei Shonagon, p 9. 
the Kokinshu ${ }^{19}$. Indirectly, she illustrated the high education level of women during that time at court. Shonagan never related past events or anticipated future incidents but described only the environment she was living in, her experiences and what she witnessed. The description of the role of a lady-in-waiting for the Empress was depicted realistically. Therefore, Makura no Shoshi is a good reference for the depiction of the life of a lady-in-waiting in the Heian period. Later, details about Shonagon's life after her court service ended became scarce.

\section{Selected Literary Works of the Heian Period}

As mentioned above two great literary works of Heian were Makura no Shoshi and Genji Monogatari. Another notable piece of literature is Murasaki Shikibu Nikki, which also provides important information in studying women's status during the Heian period. In this study, the selected literature works can be categorized into two groups, which are monogatari and nikki. Nikki is a form of zuihitsu. The term monogatari was used during the administration of Fujiwara, which referred to poetry and novels; the term was also used when referring to a new type of historical writing. ${ }^{20}$ Varley explains the meaning of monogatari as follows:

The term monogatari has been used loosely through much of Japanese history for a wide variety of writings from purely fictional prose to quasi historical chronicles. In its earliest usage however, 'monogatari' meant certain supernatural or fantastic tales that were derived both from oral folk legends and from Buddhist miracle stories written in Chinese. ${ }^{21}$

Monogatari emerged in the $10^{\text {th }}$ century. Monogatari became a special and unique outcome of the Heian court culture. Initially, the content originated in oral form Later, the creation of Katakana script supported the writing of monogatari. In the early $11^{\text {th }}$ century, Genji monogatari, the work of Murasaki Shikibu, was included in the list of the top 10 world literary works. ${ }^{22}$

Apart from monogatari, Nikki was another type of literary work in the form of daily entries that emerged during the Heian period. The first Japanese literary work using Nikki was Tosa Nikki, which was written by Ki no Tsurayuki who was a male writer and who worked as a government officer. ${ }^{23}$ According to Edith Sarra, Nikki Bungaku (a diary of memoir literature) was in the form of academic writing with traditional personal record in Japanese prose (wabun); it used native writing and Kana. She concluded that Nikki history started with Tosa Nikki, which was written by Ki no Tsurayuki in $935 .{ }^{24}$

As described earlier, Nikki is a form of zuihitsu which is literature that describes experiences, effects and stories as seen and heard by a free spirited writer. Zuihitsu is regarded as an essay. This type of work began with the story of Makura no Shoshi which

19 Ivan Morris, The Pillow Book of Sei Shonagon, p 293. Kokinshu is a compilation of old and new poetries collected in 905.

20 Paul H Varley, Japanese Culture, New York: Columbia University Press, 1973, p 64.

21 Paul H Varley, Japanese Culture, p 58.

22 Darsimah Mandah, Pengantar Kesusasteraan Jepang, Jakarta: Publisher PT Grasindo, 1992, p 9.

23 Darsimah Mandah, Pengantar Kesusasteraan Jepang, p 76.

24 Edith Sarra, Fictions of Feminity: Literary Inventions of Gender in Japanese Court Women's Memoirs, California : Stanford University Press, 1999, p 2. 
was written by Sei Shonagon. This work narrates the environment and people in a very specific manner. ${ }^{25}$ Edith Sarra also states that Makura no Shoshi can be classified as zuihitsu $^{26}$ based on its characteristics. ${ }^{27}$

\section{Murasaki Shikibu Nikki (MSN)}

Two masterpieces by Murasaki Shikibu are known by historians and lauretes as Murasaki Shikibu Nikki (Diary of Murasaki Shikibu) and Genji Monogatari (The tale of Genij). When the MSN or memoir was written, Murasaki was serving the Empress Akiko who was the favorite daughter of Fujiwara Michinaga. ${ }^{28}$ In the MSN, she describes the life at court in detail. The most significant events in Michinaga court took place after the birth of a prince to Empress Akiko in 1008. ${ }^{29}$

\section{Genji Monogatari (GM)}

In Japanese literature, the GM is known as the longest literature masterpiece in Japanese prose. The actual date when the GM was written remains unknown. Some researchers determined the date based on the daily entries by Murasaki Shikibu, which is 1 November $1008 .^{30}$ The GM is comprised of 54 chapters and is divided into two parts. The first part focuses on the life and love story of Genji. The second part is about the people in the court after the death of Genji. ${ }^{31}$ Genji was seen as a prince who had relationships with all classes of society, from the aristocratic society down to the level of commoners. The main theme of this novel was based on Genji's involvements with women. Nevertheless, Murasaki Shikibu also narrates stories of Genji's association with his friends. The relationship between men and women in the GM not only covers love affairs but also describes relationships between a child and father, husband and wife and as well as friends. ${ }^{32}$

The GM novel is perceived as a matured masterpiece because novels in the same period or earlier than the Heian period were more inclined towards fairy tales; on the other hand, some were realistic but did not demonstrate a complex development of characters or emotions compared with those portrayed in the GM. Even though the GM was an imaginative fiction, from the descriptive and psychological aspects, it relates well to the realities of community life. ${ }^{33}$

25 Darsimah Mandah, Pengantar Kesusasteraan Jepang, p 10.

26 She used the term nikki-like to denote the meaning of zuihitsu.

27 Edith Sarra, Fictions of Feminity: Literary Inventions of Gender in Japanese Court Women's Memoirs, $\mathrm{p} 2$.

28 Fujiwara Michinaga was the most powerful and famous acting Fujiwara King. He controlled the Imperial court completely between 996 and 1017. See M. Rajendran, Sejarah Jepun, Kuala Lumpur: Arenabuku, 1988, p 13.

29 R H P, Mason, and J G Caiger, A History of Japan, Rutland: Charles E.Tuttle Company, 1997, p 91.

30 Darsimah Mandah, Pengantar Kesusasteraan Jepang, p 60.

31 Paul H Varley, Japanese Culture, pp 63-64.

32 R H P, Mason, and J G Caiger, A History of Japan, p 95.

33 R H P, Mason, and J G Caiger, A History of Japan, p 96. 


\section{Makura no Shoshi (MNS)}

In this study, only one of Sei Shonagon's literature work will be discussed, which is Makura no Shoshi. Sei Shonagon wrote more poetry literary genre works than prose. Makura no Shoshi (Pillow Book) was given this name because Sei Shonagon was said to have never parted with her notebooks. Usually, these books were placed nearby or under her pillow. ${ }^{34}$ This phenomenon is also observed by Mason and Caiger:

...The writer is supposed to have kept her writing materials handily by her pillow so that she could jot down notes (at anytime of day or night) ${ }^{35}$

The MNS illustrated events or activities that described situation at court. The overall work in this masterpiece is a combination of anecdotes, reflections and observations but they are not in chronological order. ${ }^{36}$ Records of court politics, domestic affairs, affairs between the lower classes, territorial emotions and art of fiction we re someof the issues involved in the contents. In that period, Shonagon was serving Empress Teishi ${ }^{37}$ This masterpiece consists of numerous themes and generates almost 300 themes. Generally, the masterpiece is divided into two chapters and its themes fit into the literature ideology during that period, which was realizing the beauty or sense of humor normally referred to as okashi. According to Darsimah Mandah, the MNS is a compilation of stories composed when the writer felt bored and had no intention to show her boredom of what she had seen or felt. ${ }^{38}$

\section{The Status of Women in the Heian Period}

The development of women's status in Japan went through several transformations. In early Japanese history, women's status was depicted as being equal to men: as a companion to men and not as a servant. In Manyoshu, a Japanese ancient poetry anthology written in the $7^{\text {th }}$ and $8^{\text {th }}$ century, there were records of women and men dancing together after harvesting. They were married based on mutual agreements and without mediation services. ${ }^{39}$

Nevertheless, the situation changed in the $6^{\text {th }}$ century. During that time, Buddhism and Confucianism shaped the Japanese mindset. It reflected Chinese and Indian ways of life in Japanese thinking, behavior and culture. Works pertaining to women's intellectual abilities were questioned and their talents were ignored. They were assumed as followers rather than leaders, and deemed as a mere servant that stayed at home. ${ }^{40}$

34 Paul H Varley, Japanese Culture, p 63.

35 R H P, Mason, and J G Caiger, A History of Japan, $\mathrm{p} 92$.

36 R H P, Mason, and J G Caiger, A History of Japan, pp 91-92.

37 R H P, Mason, and J G Caiger, A History of Japan, p 95. Empress Teishi was also known as Sadako. She was a princess to Fujiwara Michitaka. After the death of Michitaka, his power was taken over by his brother, Fujiwara Michinaga. Later, Michinaga brought his princess, Empress Shoshi or also known as Akiko to the court. Murasaki Shikibu was said to serve Empress Akiko when her literature works were written. Lyn Reese, Murasaki Shikibu, 2001, www.womenworldhistory.com/heroine9.html, accessed on February 2013.

38 Darsimah Mandah, Pengantar Kesusasteraan Jepang, pp 79-80.

39 Paul Thomas Welty, The Asians: Their Revolving Heritage, New York: Harper Collins Publishers, 1984, p 297.

$40 \quad$ Paul Thomas Welty, The Asians: Their Revolving Heritage, p 298. 
This phenomenon also coincided with the Heian period. Women's status was not clearly described by writers in that period. Only assumptions were made based on women's literary works. However the interpretation was that women's status were categorized within the contexts of politics, social, economics, education and religion.

\section{Women and Politics}

Not many women were involved in politics due to their inability to read and write Chinese. Women were also denied educational rights in order to prevent them from taking part in politics. However, indirectly noblewomen were still involved in politics. In the MSN, the Empress is the highest ranking individual loved by her subjects, especially by those who served at court. The people at court gathered from the $20^{\text {th }}$ day of the $8^{\text {th }}$ month of pregnancy before the empress delivered her baby, underlying the concern for the Empress. ${ }^{41}$ In general, the Empress was a unification symbol of the nation due to the love of the people for her, which was equal to showing love for their country.

Women's status in politics was more visible when noblewomen married into royalty. Through marriage, relationships among families strengthened. Normally, one of the sons of the Emperor would be married off to the daughters of the Fujiwara family. This helped the Fujiwara family to be in power and maintain control of the government and bureaucracy. According to Edith Sarra, while Murasaki Shikibu failed to explain women's status official ceremonies and political marriages, she did mention few names of Fujiwara princesses who were married to members of the imperial family and gave birth to princes. ${ }^{42}$

In the period of Nara and the early period of Heian, members of Fujiwara's family held high positions in the bureaucracy and served as important advisors to the Emperor. Further, after the year 850, marriage with imperial family members guaranteed political power. Hence, it had become a custom for the son of the Emperor to be married off to a Fujiwara daughter. ${ }^{43}$ After marrying off the Fujiwara daughter of Fujiwara to the young regent, he would be persuaded later on to give up his throne on the pretext that an Emperor has huge responsibilities. Subsequently, the son from this marriage would be appointed as Emperor assisted by an Acting Emperor. ${ }^{44}$

\section{Women and Economy}

These three literary works had no detailed discussions on women's contribution to the economy. Women were usually involved in a few activities such as farming, child nursing and conducting religious rituals. In the agriculture sector, women played the role of assisting family members rather than being the main contributor although it was the most important sector at that time. Furthermore, wages for providing child nursing and conducting religious rituals were not vividly described.

41 Annie Shepley Omori and Koichi Doi, Diaries of Court Ladies of Old, Boston: Houghton Mifflin Company, 1920, p 74 .

42 Edith Sarra, Fictions of Feminity: Literary Inventions of Gender in Japanese Court Women's Memoirs, p 227.

43 R H P, Mason, and J G Caiger, A History of Japan, p 68-69

44 Azhar Mad Aros, TITAS, p 271. 
Sei Shonagon had recorded her journey to a shrine in Uzemasa. On her way there, she saw a group of farmers pulling out paddy seedlings from the plant nursery to be transferred to the paddy field. She witnessed the same action when she travelled to Kamo. Based on her description, it appeared that only men did the harvesting. This means that certain jobs were only done by men. ${ }^{45}$ However, in another story, Sei Shonagon narrated the setting of a village where she stopped to rest and eat on her way to Kamo. She saw lower-class women helping men in the paddy field. She witnessed women harvesting paddy. This explains the different contributions of women according to districts. Further, she further narrated that women also contributed in terms of labor in paddy fields or vegetable farms in most of the districts. ${ }^{46}$ Apart from farming, Sei Shonagon also shared a story on a woman given special status in society when she nursed a baby boy instead of a baby girl. ${ }^{47}$ Nevertheless, wages paid to the woman was not revealed. In the MSN, it was only mentioned that courtier and nanny were rewarded with cloth or kimono and hakama based on their rank within the court. For nannies of the court, they would be given cloth and baby's clothing. ${ }^{48}$

The GM narrates clearly the function of women as a conductor in religious rituals. For example when Aoi, one of the wives of Genji was critically ill, a girl who was wellknown as 'Virgin of Ise' was called to treat Aoi ${ }^{49}$ During this period, medical practice was said to be related to religion as medical practitioners were priests and used religious rites. The MNS also cites two priests who were given cloth by the Empress when they visited court. At other times, they came to the place to obtain contributions for the shrine.

\section{Women and Social Experiences}

Women experienced two different environments during the Heian period. For lowerclass married women, they stayed at home to take care of their husbands and did not pursue any ambitions. Nevertheless, they felt contented and happy. According to Shonagon, even though some of the women were talented and smarter than men, they did not have an opportunity to see the world. Therefore, lower-class women had a closed-minded attitude. Noblewomen or women who worked in the court had better opportunities to see the outside world, and they were allowed to mingle with the community. ${ }^{50}$ Heian community despised lower-class women. Whatever these women said would be regarded as impolite even though they had good intentions like complementing someone. During that time, complementary words from lowerclass women were regarded as disgracing a higher ranking person's pride. In fact, the company of women from the lower classes was regarded as being able to ruin the reputation of higher ranked women in general. ${ }^{51}$

45 Ivan Morris, The Pillow Book of Sei Shonagon, p 212.

46 Ivan Morris, The Pillow Book of Sei Shonagon, p 119.

47 Ivan Morris, The Pillow Book of Sei Shonagon, $\mathrm{p} 47$.

48 Most probably the nannies also had their own babies and the clothes given by the Empress were for their own infants. Annie Shepley Omori and Koichi Doi, Diaries of Court Ladies of Old, p 90. Most probably the nannies also had their own babies and the clothes given by the Empress were for their own infants.

49 Ivan Morris, The Pillow Book of Sei Shonagon, p164.

50 Ivan Morris, The Pillow Book of Sei Shonagon, p 39.

51 Ivan Morris, The Pillow Book of Sei Shonagon, p 248. 
In other instances, a married woman would normally live permanently with her family. A man either would choose to stay with his wife and her family or would only visit her once in a while. ${ }^{52}$ Men had freedom to have affairs with other women outside their homes even though they were married. This situation was depicted clearly in the GM. After Genji was married to Aoi, they were not living under the same roof. Genji had his own court. For instance, on one occasion when Aoi was critically ill, a courtier was sent to Genji's court to inform him of his wife's condition. ${ }^{53}$ Genji also had secret affairs with other women even though he was married. It is reputed that among his most loved girlfriends was Murasaki.

Although his affairs with other women were known by his wife, normally nothing could be done by wives. Even as a wife, a woman's rights were vague. This was further worsened by women's attitude during by those days who were willing to be mistresses or lovers to married men. However, the most important issue was that marriages were based on love or mutual feelings. This shows that women had equal rights when choosing life partners or having a love affair with men. Sei Shonagon still voiced her dissatisfaction toward men's unequal attitude towards women. This attitude and unfair treatment applied to both adult women and children who were girls. In the MNS, she related how a husband of a nanny would stay away and could not care less about the baby girl under his wife's care. However, if it was a baby boy, the husband assisted his wife and would give very special attention to the baby boy. ${ }^{54}$ Men gained higher status in the community when they had a son. It was the same for a nanny's husband. The husband was in a better position and indirectly gained power in court when his wife was the nanny to a baby boy from a noble family.

It is obvious that in the Heian period, women had equal rights in some issues but mostly has a low status. For Japanese community, having a son is believed to bring prosperity to the family. Men were appreciated and families that had sons were given higher status.

\section{Women and Education}

Based on cultural practices during the Heian period, women were not allowed to receive formal education and express their thoughts. For example, in the GM, one of Genji's friends profossed that women should pretend to be lacking in knowledge even though they were highly educated. ${ }^{55}$

The influence of Chinese language, culture and politics was quite significant in the Heian court/ For many decades, Chinese script was used in government official records and documents. The main purpose of the usage of the language and writing was to limit the involvement of certain groups in politics. Chinese education was normally controlled by aristocratic men. This was stated by Edith Sarra:

Education in Chinese was generally restricted to men of the aristocracy. Aristocratic women were carefully educated to read and write Japanese poetry... ${ }^{56}$

\footnotetext{
Ivan Morris, The Pillow Book of Sei Shonagon, p 269.

Arthur Waley, The Tale of Genji by Lady Murasaki, translated from Japanese, p 168.

4 Ivan Morris, The Pillow Book of Sei Shonagon, p 47.

55 Arthur Waley, The Tale of Genji by Lady Murasaki, translated from Japanese, p 36.

56 Edith Sarra, Fictions of Feminity: Literary Inventions of Gender in Japanese Court Women's Memoirs, p 2.
} 
Therefore, women were not taught to read or write Chinese. Nonetheless, some women were able to learn to read and write Chinese. These women were normally noblewomen who were brave enough to break traditions. Among these women was Murasaki who learned to read and write secretly from her father and from her brothers. ${ }^{57}$ In other words, noblewomen were luckier because they had the opportunity to receive education; their families were able to provide them with lessons in either reading or writing Chinese or Japanese. They also had opportunities to obtain reading materials from China or literature works written by Japanese which was compiled in the court. During that time, the court was the center for books and any reading materials. In terms of time, noblewomen had opportunities to focus on writing compared with common or lower-class women who had to work in the farms to assist their families. ${ }^{58}$

\section{Women and Religion}

In the MNS, Sei Shonagon analyzed women from the perspective of status and religion and made comparisons with women prior to the Heian period. Women of higher classes were allowed to visit temple places and interact with the monks. Meanwhile, women of lower classes were only allowed to listen to religious rites. Before the Heian period, women seldom visited or attended religious rituals. They were restricted to wear only a special type of outfit, which was a white gown normally worn during religious rituals. ${ }^{59}$

Another event told by Sei Shonagon was the Special Festival in Kamo. A performance called "Sacred Dance" was staged in the shrine, performed by women. Most of the people in Japanese society loved this dance ${ }^{60}$ Besides, she also mentioned the Highest Priestess from the Highest Shrine ${ }^{61}$ who was a woman. The priestess supposedly conducted an important ritual called "Return Procession." The ceremony was attended by the Emperor and Empress (Morris, 1967: 202). In other words, the GM perceived women having no restrictions in religious activities. For example, Fujitsubo was one of the emperor's wives who had become a priestess who gave up her position in the state to dedicate her life to religious activities. ${ }^{62}$ As stated in the MSN, Murasaki Shikibu read sutras and often prayed. She focused on sutra reading in depth and tried to understand it. She also related her feelings of surrendering herself to religious life. ${ }^{63}$

Even though textual history states that women were not given opportunities to contribute in many sectors, the area of religion was an exception. In fact, certain religious rituals show the importance of women as a conductor in communicating with supernatural powers. This service was welcomed and acknowledged by the state.

57 Lyn Reese, Murasaki Shikibu, 2001, www.womenworldhistory.com/heroine9.html, accessed on March 2013.

58 During the Heian period also, there was the emergence of Japanese poet anthology, which was Kokinshu (905M). Most of these poet writers comprised women. Lyn Reese, Murasaki Shikibu, 2001, www.womenworldhistory.com/heroine9.html, accessed on 12 February 2013.

$59 \quad$ Ivan Morris, The Pillow Book of Sei Shonagon, p 55.

60 Ivan Morris, The Pillow Book of Sei Shonagon, 162.

61 Shrines in Japan also have hierarchy. The Highest Shrine is a temple normally visited by the upper class and imperial families. It is an important religious place for the purpose of royal religious rituals and activities.

62 Arthur Waley, The Tale of Genji by Lady Murasaki, translated from Japanese, $\mathrm{p} 216$.

63 Annie Shepley Omori and Koichi Doi, Diaries of Court Ladies of Old, p 137. 


\section{Depiction of Women by Murasaki Shikibu and Sei Shonagon}

According to these two writers, in general, women in the Heian period were restricted to living within the imperial court. This in turned limited their roles, and hence did not have much impact on the community at large. Some of these jobs were often mentioned by Murasaki Shikibu and Sei Shonagon, and they were assumed by women in the court. Amongst the roles attributed to them were being a nanny or wet nurse, conductor of court ceremonies or being a courtier, waitress, door keeper, messenger, entertainer and teacher.

\section{The Role of a Nanny}

In court, it was common for a baby to be breastfed by a woman who was not his or her mother. In fact, the first breastfeeding ceremony would be done on a big scale. In the MSN, a nanny named Tachibana (Rank 3) was chosen to breastfeed a prince. Besides that, another other nannies were appointed, namely Daisaemon-no-Omoto, the daughter of Munetoki and Kurodo-no-Ben, ${ }^{64}$ The GM also shows the extent to which women played an important role in nursing children of noble families. For instance, Genji had appointed a nanny to take care of Murasaki. ${ }^{65}$ Sei Shonagon further elaborates on a nanny's task. Normally, a nanny was highly regarded because a baby would face problems when separated from his or her nanny. On one occasion, a nanny fell in love with someone and had to leave the baby under her care to meet her lover. The situation became chaotic when the baby cried non-stop. In the end, the nanny was called home to attend to the baby. ${ }^{66}$

\section{Court Ceremony and Religious Conductor or Assistant}

One of the important court ceremonies was a prince's bathing ceremony. Among the names mentioned by Murasaki Shikibu was Madam ${ }^{67}$ Kyoiko and Madam Harima who were in charge as cold water dispensers; Omoku and Uma were the clean water selectors; Madam Saisho was tasked to bathe the prince. However, important ceremonies could always be conducted by men. A priest from Henchi Shrine was the protector of the prince and Sir Munetoki (Governor of Ise) recited the Kokyo in the royal household, which is the sacred book. But most of the courtiers were chosen from a group of young and beautiful women. ${ }^{6}$

The GM also depicts that women played an important role in religious and medical ceremonies. When Princess Aoi who was the wife of Genji fell sick, an unmarried woman was chosen as the conductor of soul in medical ceremony. Among the chosen women mentioned in the GM were San no Miya, the daughter of Kokiden and another woman called "Virgin of Ise". ${ }^{69}$ Genji also mentioned Princess Asagao who was appointed to replace the daughter of the Emperor, husband to Madam Kokiden. Princess Asagao

\footnotetext{
4 Annie Shepley Omori and Koichi Doi, Diaries of Court Ladies of Old, p 82.

65 Arthur Waley, The Tale of Genji by Lady Murasaki, translated from Japanese, $\mathrm{p} 132$.

66 Ivan Morris, The Pillow Book of Sei Shonagon, p 41.

67 Some names mentioned in Murasaki's work begin with the title Madam, showing some women having a higher status compared with other women in court. However, these women's status and rank were not elaborated.

68 Annie Shepley Omori and Koichi Doi, Diaries of Court Ladies of Old, p 84.

69 Arthur Waley, The Tale of Genji by Lady Murasaki, translated from Japanese, $\mathrm{p} 164$.
} 
was appointed as "The Vestal Virgin of Kamo" a post appointed personally by the emperor. Her main task was to carry out royal religious rituals together with high priests from the Shrine. ${ }^{70}$

Sei Shonagon also mentioned the Highest Priestess from Kamo. Sei Shonagon witnessed an important religious ritual and was looking forward to seeing the priestess at the Highest Shrine in Kamo. The priest was described as a beautiful woman; she traveled in an ox-carriage and was escorted by a group of men from the Emperor's Personal Department. ${ }^{71}$

\section{The Role of a Servant}

In the MSN, Murasaki Shikibu explains clearly the real task of a lady-in-waiting for the Empress. One of her important tasks was to entertain the Empress during meals. Eight women were required to entertain. Each of these ladies had to take turns to be the head lady-in-waiting during the meal. These ladies were mentioned as Special Ladiesin-waiting. Among the names mentioned by Murasaki Shikibu was Minamoto Shikibu who was the daughter of the Kaga Province Governor; she also highlighted Kozaemon who was the daughter of the Governor of Bitchu, and Osuke who was the daughter of High Priest of the Ise Shrines. ${ }^{72}$ Sei Shonagon as well as Murasaki Shikibu also performed the role of a lady-in-waiting for the Empress. Besides being a lady-in-waiting for the Empress, they also had their own courtiers. In the MNS, when Sei Shonagon came back late from the Court of Umetsubo the following day, her courtier was waiting for her and briefed her about the presence of a messenger from the government. ${ }^{73}$

In the GM, Genji's lady-in-waiting had more or less the status of a servant. On one occasion, Genji instructed his servant who was a woman to just pluck a flower from the garden. Here, the task of his servant was to serve and accommodate Genji. Her task was not so important because Genji was only an isolated prince since he had no important position in the court. ${ }^{74}$

\section{The Role of a Door Keeper}

Sometime, women are door keepers. Murasaki narrated the condition of gatekeepers of the east door whose dresses were unkempt and hairs were not well groomed with pins. ${ }^{75}$ This explains that one of the tasks of courtiers was to man the entrance door to the Empress Court. However, in the MNS, Sei Shonagon seldom talked about this task. One incident took place after midnight when one of the courtiers was assigned to open the door when a visitor came to the court entrance. That night, there was a musical performance in the hall. ${ }^{76}$ However, there was a possibility that the woman was assigned to a different department but when the need arose to open the door, she was assigned on the spot to do it. Being a doorkeeper perhaps was not a permanent job for the lady-in-waiting.

\footnotetext{
70 Arthur Waley, The Tale of Genji by Lady Murasaki, translated from Japanese, $\mathrm{p} 210$.

71 Ivan Morris, The Pillow Book of Sei Shonagon, p 198.

72 Annie Shepley Omori and Koichi Doi, Diaries of Court Ladies of Old, p 87.

73 Ivan Morris, The Pillow Book of Sei Shonagon, p 93.

74 Arthur Waley, The Tale of Genji by Lady Murasaki, translated from Japanese, p 54.

75 Annie Shepley Omori and Koichi Doi, Diaries of Court Ladies of Old, p 89.

76 Ivan Morris, The Pillow Book of Sei Shonagon, p 259.
} 
The Role of a Messenger for the Royalty

Women, acting as a messenger was one of the tasks often mentioned in Japanese literature. In the MSN, Murasaki mentions Senji or a messenger of the Empress, whose task was to deliver messages to outsiders. ${ }^{77}$ In GM, after the death of Kiritsubo who was Genji's mother in her hometown, the Emperor sent his messenger to Kiritsubo's home. The messenger was a woman who was the most trusted courtier. She conveyed the exact words spoken by the Empress who requested Genji to go to the court. ${ }^{78}$ Also in the MNS, Sei Shonagon states several times the presence of messengers from other courts. Most of these messengers were women. For example in then MNS, Sei Shonagon only mentioned one male messenger. In other instances, the messengers were all women. ${ }^{79}$

\section{The Role of an Entertainer}

In certain court ceremonies, entertainment was required. A common performance was dancing. Dancing was not only performed for the sake of entertainment but also performed at important festivals and for religious purposes. Dancing was the main topic of men's conversations as most dancers comprised daughters of imperial families. For instance, among the dancers was the daughter of the Royal Advisor and State Counselor. ${ }^{80}$ Besides dancing, women also had the ability to play music. In the GM, woman played music as well as men. For instance, when Genji was walking in the village of Ummeiden, he saw a woman playing a flute, who later was often invited to play music together with other royal professional musicians. ${ }^{81}$ In the MNS, Sei Shonagon talks about the visit of the Emperor to the Empress's room, where he brings along a flute called mumyo. The mumyo then was played by a few of the Empress's courtiers. ${ }^{82}$ The ability of women to play musical instruments was acknowledged by men, including the Emperor who instructed the Empress's courtiers to play the musical instrument. Women were entrusted to play the instrument instead of men.

In the GM, Murasaki Shikibu describes a different environment when the dancers were males. However, when men became entertainers, they were appreciated more than women. In addition, their ranks would be elevated in the court if they performed well. ${ }^{83}$ Meanwhile, none of these three literary works mentions the ranks of female dancers being elevated in any form.

\section{The Role of a Teacher}

In the MSN, Murasaki Shikibu records that the Empress had asked her to read poetry by Li T'ai Po. Murasaki also taught her to read that poetry secretly for two years. When the Emperor and Prime Minister knew about this, both of them gave the Empress many

\footnotetext{
Annie Shepley Omori and Koichi Doi, Diaries of Court Ladies of Old, p 111.

Arthur Waley, The Tale of Genji by Lady Murasaki, translated from Japanese, p 10.

Ivan Morris, The Pillow Book of Sei Shonagon, p 43.

Annie Shepley Omori and Koichi Doi, Diaries of Court Ladies of Old, p 117.

Arthur Waley, The Tale of Genji by Lady Murasaki, translated from Japanese, $\mathrm{p} 142$.

Ivan Morris, The Pillow Book of Sei Shonagon, p 112.

3 Arthur Waley, The Tale of Genji by Lady Murasaki, translated from Japanese, p 131.
} 
poetry books. According to Edith Sarra, Murasaki Shikibu was asked by Fujiwara Michinaga to be a tutor to his princess. ${ }^{84}$

Sei Shonagon was also often requested by the Empress to write poetry and to write down their discussion. For example, there were records of their discussion on love; they talked about their views on wether it was better to be loved or not to at all. On another occasion when Sei Shonagon was seeking inspiration to write her poetry song, she asked for permission to go out, and she went to the village area. But there were times when she had no ideas and could not produce any but yet the Empress forced her to write poetry..$^{85}$ Even though Sei Shonagon did not teach the Empress directly, she was needed by the Empress to write poetry and literary works. It seems that the Empress listened to Sei Shonagon's opinions and views. In the GM, there were some servants or ladies-in-waiting who also taught Genji. Nevertheless the subject matters were about the natural environment and culture or community life. ${ }^{86}$

\section{Conclusion}

Based on the role of women discussed above, it is obvious that women were very much needed in formal and informal settings. Those women who played an important role were not only noblewomen but also women from the lower classes of society. Normally during that period, women were given gifts as a token of appreciation for their work. In all the literary works discussed, women were appreciated by the Empress and Emperor because they had done a good job. Hence, it is not surprising that they were rewarded with beautiful and expensive cloth. Therefore, in general, it can be concluded that women's role and function were recognized by the ruler and community. Although women at that time were denied rights and privileges to an education, they accepted their fate and did not show any dissatisfaction towards the discrimination. This is partly because they grew up in a society that discriminated women. Their second-class treatment became a life style which did not give them a voice in society.

\footnotetext{
84 Edith Sarra, Fictions of Feminity: Literary Inventions of Gender in Japanese Court Women's Memoirs, p 17.

85 Ivan Morris, The Pillow Book of Sei Shonagon, p 118-120.

86 Arthur Waley, The Tale of Genji by Lady Murasaki, translated from Japanese, $\mathrm{p} 34$.
} 